\title{
CATHOLIC LAITY INVOLVEMENT IN CHURCH BUILDING PROJECT
}

Management of church building projects in the Hong Kong Catholic Diocese from the 1960s to present

\author{
教会堂建設事業における一般信徒の参加 \\ 1960年代以降のカトリック香港教区による教会堂建設事業マネジメント
}

\section{Ayako FUKUSHIMA*}

福島綾子

\begin{abstract}
The Hong Kong Catholic Church introduced laity involvement in building project management for worship places in the 1970s. Following the liturgical reforms established by the Second Vatican Council in the early 1960s, the Diocesan Liturgical Commission in the late 1970s commenced initial measures to involve the laity. However, their influence remained limited until the early 1990s. Then, the Diocesan Building and Development Commission (1995) promoted an increase of professional laity from the building industry through the highly organized commission. It provided laity with substantial policy and decision-making influence, resulting in the establishment of a standardized project management method.
\end{abstract}

Keywords : Catholic, church, Hong Kong, building project, laity カトリック，教会堂，香港，建設事業，一般信徒

\section{Introduction}

The Catholic Mission in Hong Kong was established in 1841 in the same year as Hong Kong became a British colony. Since the Second Vatican Council (Vatican II) in the early 1960s, endeavors to involve the laity in building projects for worship places and other Diocesan properties began. ${ }^{1,2)}$ This study identified three development phases of professional laity involvement after the 1960s. The first phase is the 1960s to the mid 1970s in which the foundation of laity involvement in various church management began to be laid. The second is the late 1970s to the early 1990s when the laity professionals from the building industry began to be organized in the Diocesan structure. In this phase, involvement remained to be ad hoc and their influence in project delivery was limited. The third is from the mid 1990s to present, when a Diocesan commission solely dedicated to building project management was set up in which laity involvement became firmly established and systematized.

The characteristic of laity involvement in Hong Kong is that it is highly organized and systematized in Diocesan structure, which is rarely found in other regions. ${ }^{3)}$ It is assumed that laity involvement patterns are diverse and unique in different regions. Although previous studies have revealed mission strategies of the Catholic Church in Hong Kong in the 19th century as well as from the 1950s to the 1970 s, little attention has been paid to the involvement of lay members in building project management. ${ }^{4,5,6)}$

The laity professionals in the third phase, especially laity architects who provide general advices, select the consultant architect for design and supervision, check cost and construction and so on, always belong to the client side, which is the Church. They should be distinguished from consultant architects and contractors who provide services based on the contract with the Church. In this system, the Church internal laity professionals are expected to be a guarantee for the contract to be implemented according to contract terms.

This paper focuses on laity professionals with the aim (1) to identify different phases of laity involvement, and (2) to reveal the situation of institutional systematization in each phase as well as professionals involved in church building management in the Diocese since the $1960 \mathrm{~s}^{7}$

2. Management of Building Projects from the 19th century to the Early 1990s

2.1 Traditional lack of laity involvement, the 19th and the first half of the 20th century

\footnotetext{
* Assistant Prof., Department of Environmental and Heritage Design, Faculty of Design, 九州大学大学院芸術工学研究院環境・遺産デザイン部門 Kyushu University, MSc in Historic Preservation 助教・修士 (科学)
} 
According to research by Louis Ha, Hong Kong Catholic Mission started in the 19th century as Rome's (Propaganda Fide, headquarter of Roman Catholic Mission in Rome) financial office, "Procura(later known as Procuration)". Procura was headed by the procurator who was in fact Rome's representative and its financial manager for China missions. ${ }^{8}$ Ha explains how powerful Procura was in all the missionary activities: "very often the financial capacity determined how far the missionary work could go. Consequently, the person who had control over money was the man who gave orders." ${ }^{9}$ ) Since the beginning of the Mission, the procurator handled and was the most influential in decisionmaking on all building projects such as where and how to build, renovate, rebuild and finance churches. This tradition had been handed down until the early 1990s. In 1992, the responsibility of the Procuration is summarized as below: "The Diocesan Procuration deals with financial matters pertaining to the diocese, parishes and diocesan schools. Up to this point (1992), it was also responsible for development projects such as the building of new churches and the applications for running a new school."10) This remark suggests that a building project was regarded as a financial matter.

Fig.1 shows that Catholics grew tremendously in number after the war and worship places grew before and after the war. Increase of the Catholics corresponds with the large and rapid influx of refugees and immigrants from the Mainland China after 1949. The number of worship places grew rapidly since the 1920s because statistics after 1919 start including the number of "stations without proper chapels". Decreased worship places after 1958 may reflect that a number of worship places, especially "stations without proper chapels", were closed down during WWII. ${ }^{11)}$ The major building types for places of worship constructed during the period from 1949 to the early 1960s was the complex of refugee service centers and church-cum-schools, which were the result of the missionary strategy as well as the social needs at that time. ${ }^{12)}$ Worship areas were usually included

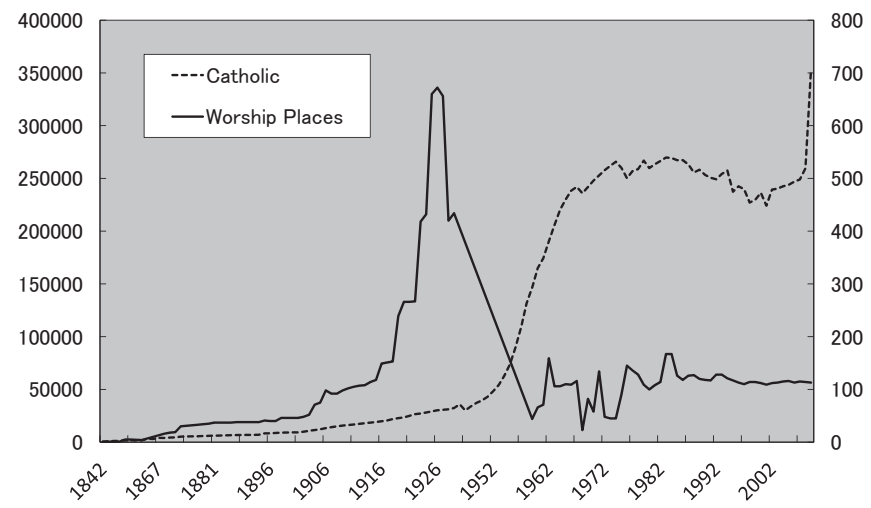

Fig.1 The number of Catholics and Worship Places in Hong Kong (created by the author based on reference 2; Hong Kong Diocesan Archives Section I) in those complexes.

As for the laity or parishioners as end-users of worship places, they had no say in how to build or renovate their own church. Li Ng states that, by the mid 1960s, "lay participation, if not totally lacking, was poorly coordinated and was marginal. As regards to decision-making and the running of the diocese, lay participation was nil." ${ }^{13)} \mathrm{Li} \mathrm{Ng}$ also describes "pre-conciliar (preSecond Vatican Council) state" of the Church as: "poor (or little and informal) channels of communication (between clergy and laity); ad hoc problem-solving style; reliance on individual and amateurish efforts and initiatives." ${ }^{14)}$ Design of new worship places were discussed and decided between the parish priest and a consultant architect employed for the project. Even though some laity offered help for building projects, parish priests did not usually take up such offers because most of them were more concerned about pastoral and spiritual matters. As a result, it caused dissatisfaction and frustration among parishioners. ${ }^{15)}$

2.2 The Second Vatican Council and establishment of Diocesan Liturgical Commission(DLC), the 1960s to mid 1970s

Vatican II was summoned by Pope John XXIII from 1962 to 1965 in order to adapt the Church to the contemporary requirements of its apostolic task. Vatican II had a significant impact on organizational structures and the change towards problem-solving style of the local diocese. ${ }^{16)}$ Importantly, it urged such post-conciliar developments as the redefined role and importance of the Church and governance by committee rather than through absolute rule by a single individual such as the bishop or the procurator. Following Council directives, the local diocese established very rapidly during the period of 1964 to 1974 , functionally specialized units of diocesan commissions and committees to study and respond to the various needs and problems of the diocese in light of Council teachings. ${ }^{17)}$ Table 1 shows the names and duration of appointment of the bishop and procurator along with the diocesan commissions/committees whose task included building projects with the period they existed. The DLC was created in May 1964 in order to conform to new liturgy announced in Vatican II. ${ }^{18)}$ One of the main themes of Vatican II was renewal of the liturgy, which brought significant and widespread changes to church buildings around the world. ${ }^{19)}$ The foundation to involve laity in church management was laid by this reform.

2.3 Shift Towards Laity Professional Involvement in the Late 1970s to Early 1990s

2.3.1 Establishment of Liturgical Art and Architecture Committee(LAAC) in the late 1970s

The LAAC was established in 1977 as one of sub-committees under DLC (table 1). LAAC's "tasks are: to establish liturgical architectural and art disciplines of the Diocese; evaluate and advise on designs for construction, restoration and renovation of churches and mass centers prepared by the Diocesan Procuration; 
Table 1 Bishops, Procurators and Diocesan Commissions related to Building Projects (created by the author based on reference 5, 1953-2010)

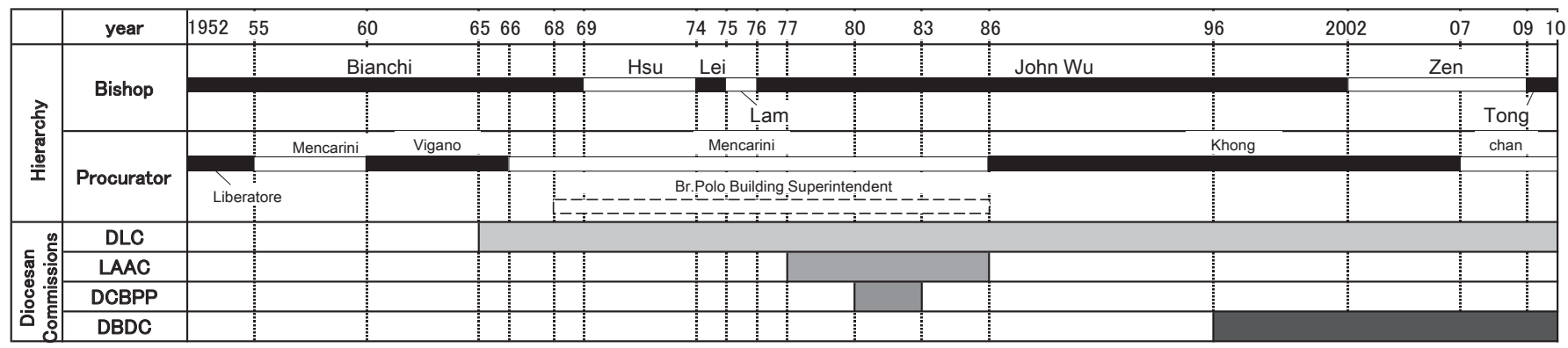

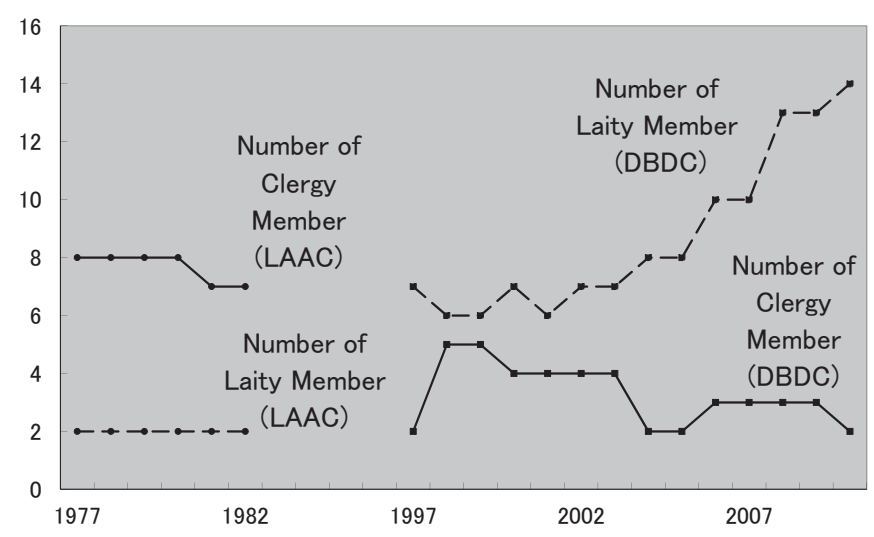

Fig.2 Number of Clergy and Laity Members of LAAC and DBDC (created by the author based on reference 5, 1978-2010)

explore localization of liturgical architecture and arts." ${ }^{20)}$ Vatican II's liturgical reforms caused a great deal of confusion in the Church. The LAAC was meant to become a clearinghouse for liturgical spaces matters. The DLC also commented, "The Commission (DLC) believes that the establishment of this committee (LAAC) will, more importantly, be able to reduce waste or loss of money in architectural issues of the Diocese and also help newly built churches meet new liturgical requirements." ${ }^{{ }^{21)}}$ It implies that the LAAC was also given the task to reduce problems in building projects.

Fig.2 illustrates how human resources were mobilized in the LAAC to confront such problems. At the time of its establishment in 1977, the LAAC had 10 commission members in total, most of whom were clergy including a Religious Sister. There were two laity members, one of which was an architect and another was the Director of the Hong Kong Museum of Art. ${ }^{22)}$ In addition, there were several lay consultants, who were not official members of LAAC, including an architect who was then the Head of the Department of Architecture of the University of Hong Kong. ${ }^{23)}$ Because the LAAC's mission emphasized liturgy, the clergy members had a larger proportion of membership. Although the DLC and the LAAC together gave advice on liturgical spaces in building projects, neither of them were given a position to plan, coordinate, monitor building projects, or make any decisions. It was the procurator who was the most influential in making those decisions. In addition, the LAAC was an ad-hoc committee being a sub-group of the DLC; hence, its scope and influence were limited.

Officially, the LAAC was dissolved in 1983 "to be reorganized." ${ }^{\text {"4) }}$ The LAAC disappears from the official list of diocesan organizations in 1986. However, various documents and interviewees from this study show that it kept functioning after 1983 up to 1995 . It was also confirmed that a few architect laity remained to serve as members.

Despite its limited power, the LAAC was an important milestone for the Diocese to mark the first step of a gradual involvement of laity, especially professionals in the building industry, in diocesan building projects.

\subsubsection{Impasse of Traditional Management Method in the 1980s}

According to $\mathrm{Li} \mathrm{Ng}$, "the post-conciliar principle that the laity and the hierarchy should cooperate and share in the mission of the Church was accepted in theory, but the view of Church personnel is that the laity is not yet fully prepared to practice their new responsibilities, nor is the system for achieving this goal wholly sound. In the parishes, the clergy still reigned supreme in lay apostolate affairs." ${ }^{25)}$ From the late 1950s to the early 1970s, the decrease in vocations to priesthood and sisterhood, and the rapid increase in total population as well as in Catholic membership, aggravated the perpetual problem of insufficient work force. All too often, priests were allocated too many responsibilities to really carry them out well. ${ }^{26)}$ This situation remained true in the 1980s as well.

The 1980s became a period of physical renewal for many places of worship. At the same time, There was a need to build more new schools, which also housed worship places inside. ${ }^{27)}$ This was due to continuing population growth in Hong Kong followed by urban sprawl to which the Diocese had to respond as a social benefactor in welfare, education, and medical care for the Hong Kong society. ${ }^{28)}$ Consequently, there were an overabundance of projects to be dealt by the procurator.

The "Building Superintendent", in-house staff in the Procuration office, served from 1968 to 1984(table 1). He was an Italian Religious Brother and managed all the diocesan building projects. ${ }^{29)}$ However, after his death in 1984, no replacement as a full-time "Building Superintendent" was arranged in the 
Procuration.

In 1992, the procurator mentioned that "the diocesan procurator (is) assisted by a professional architectural consultant who acts also as Project Manager for specific construction projects." ${ }^{30)}$ "Architectural consultant" was a laity architect, who was one of LAAC laity members, serving on a voluntary basis. ${ }^{31}$

"Clerk of Works" (COW) were employed as full-time staff by the Procuration to assist the building project. COW was site superintendent of works under the direction of architect and engineer.

The 1970s and 1980s were the beginning of involving the laity professionals in church building projects in the Hong Kong Diocese. Involvement during this phase was rather ad hoc and not systematically organized in the Diocesan structure.

With regard to project management method, all the interviewees in this study pointed out that one of the problems in diocesan building project was that the Diocese had not adopted a standard project management method generally employed in the building sector. A tendering system and procedure had not been established.

Due to all those factors, an increasing number of technical defects in newly constructed churches were reported. ${ }^{32)} \mathrm{An}$ increasing number of stakeholders in the Church became convinced that there should be a standardized method for building project management in the Diocese.

2.3.3 DLC's Initiative for Reform from the late 1980 s to the early 1990s

In the late 1980s, the DLC commented on the laity involvement as follows: "there is very little that the Church or religious communities or worshipping communities have done to bring some development whether in architectural styles, or interior design or works of religious art. ... There are experts available in all fields of art in Hong Kong, may we not consider their opinions in our deliberations." ${ }^{33)}$ It indicates that the Church still had little laity professional involvement during this period.

Reverend Thomas Law, a secular priest of the Hong Kong Diocese, came back from his study in Italy to Hong Kong in 1985. Soon after his return, with his strong specialization in liturgy, he took up the position of Director of the DLC office as well as one of Coordinators of it. The DLC's initiative led by Law along with other clergy members of the DLC began to reform the traditional building project practice and establish a standardized management method as well as an appropriate body for management. Since the late 1980s and up to the early 1990s, it kept writing letters and proposals to the bishop suggesting the establishment of a new commission solely dedicated to building project management.

The LAAC, a sub-committee of DLC, was given a task to compile the "Proposal for the Establishment of a Client Body for All Construction, Alteration and Maintenance Works of the
Hong Kong Diocese" in 1988 as a suggestion to the procurator and other stakeholders in the Diocese. The proposal suggested to create a "Building \& Construction Committee" or "Project Team" as a centralized representational body for a group of clients for building project that consisted of procurator, bishop, parish priest, DLC, architects or project manager and consultants. It was also suggested to appoint a "Project Manager" to represent the Project Team who can professionally deal with other consultans and contractors.

The proposal in 1988 was not officially put into practice. However, a group equivalent to a "Project Team" was informally and gradually formed in practice by 1992 involving procurator, DLC/LAAC and parishes in church building projects. Gradually the procurator shifted to more "of the finance control side; whereas, the design and supervision are left to the other two parties (parish and the DLC/LAAC).”34) However, at the same time, the demand for a full-time and permanent professional staff or commission for building projects became greater.

2.3.4 Bishop Wu's Diocesan Reorganization from the late 1980s to the early $1990 \mathrm{~s}$

Reverend John Baptist Wu Cheng-Chung, the 5th Bishop of Hong Kong Diocese, implemented various reforms of the Diocese (table 1). In 1987, the Diocese launched a comprehensive study and consultation project in order to identify what directions the Church should take in the next ten years. During the consultation, many Church members, including clergy and lay members, "proposed to make use of all possible ways to upgrade the status of the laity in diocesan organizations and to increase their participation in every kind of Church undertaking." ${ }^{35}$ Recommendations following the consultation also included to "readjust the administrative structure of the Diocese to permit more lay people to participate. It should set up a laity resources centre to make good use of the talents and resources of the laity."36)

In 1992, Bishop Wu announced the "Plan for the re-organization of the Diocese", which was another plan for reform. The principles adopted for reorganization included "making provisions for a wider and more active participation of lay people in the life of the Church, enhancing their consultative role." Also in the plan was a proposal to revive the "Diocesan Commission for Building Projects and Planning (DCBPP)", which existed from 1980 to 1982 (table 1). The objective of the DCBPP was to carry out the following two steps: 1) to assess the present situation of the Diocese in terms of its physical presence, that is, whether all geographical areas of the Diocese are appropriately and adequately served by the Church in terms of a proportionate distribution of church buildings, such as churches, chapels, mass centers, schools and other institutions in those areas, and 2) to make future plans. The members of the Commission were suggested to consist of: a Vicar General, the Diocesan procurator, one priest each from Hong Kong, Kowloon, and the New Territories, and two to three lay professionals. ${ }^{37)}$ This 
suggested member composition of the DCBPP has a slightly larger proportion of clergy members than the laity. Yet the gap is not as big as that of the LAAC. Though the DCBPP's responsibility was not specifically set for building project management, it is still important to notice that it was given a task to make policies for diocesan building projects, which included laity professionals.

Right after the announcement of the reorganization plan in 1992, a detailed action plan for this new "DCBPP (renamed in the action plan as the "Diocesan Planning and Land/Building Development Commission")" was developed by the DLC, and was submitted to the bishop. ${ }^{38)}$ The action plan for a new commission was more detailed and more practical than the previous 1988 proposal. However, despite this, the commission was not realized. Yet the DLC's internal documents show that it together with the LAAC kept making preparations to set up a new commission. Members did extensive research on how project management worked in the building industry and what regulations were compiled by Hong Kong Institute of Architects. Reverend Law compiled a list of "professionals" as architects, engineers, surveyors etc. among laity whom he knew, and who could possibly become the founding members of a new commission.

\subsubsection{Proposal to the Bishop in the mid 1990}

In a gathering attended by the Bishop Wu and many laity in 1995, one of the lay members raised the issue about church buildings by pointing out the insufficient communication between the parish priest and the parishioners in church design, which resulted in dissatisfaction of parishioners. Simon Li, a property management professional working for the Housing Department of the Hong Kong Government (retired in 1998), who was also present, shared the same opinion and believed that participation of laity with professional backgrounds in the building industry would improve the situation. After the gathering, Li was asked by Bishop Wu to work with Reverend Dominic Chan, Vicar General, to make a proposal to him for the purpose to improve the situation. By that time, the Bishop himself was keenly aware of problems regarding buildings projects. ${ }^{39)}$ Rev. Chan and Li, in their proposal to the Bishop, stressed that the Diocese should establish a diocesan commission, which substantially involves the laity as professionals in building projects.

\section{Building Project Management Since 1995}

By late 1995, Bishop Wu finally put into force a new and permanent commission dedicated to diocesan building projects by involving more laity professionals, which was named the "Diocesan Building and Development Commission (DBDC)". DBDC's first meeting was held in December 1995.

\subsection{DBDC members}

Table 2 summarizes all the DBDC members who have served in the past. Laity members are organized by chairperson, vice chairperson, other appointed members and DBDC office staff.
Table 2 also divides appointed members by their profession as architect, structural engineer, quantity surveyor, building services engineer, planner, civil engineer and other. Clergy members are organized as Ex-officio members and others. The grey bar for each member indicates the duration of appointment.

All DBDC members serve on a volunteer basis, as do other members of Diocesan Commissions. Commission members are appointed by the Bishop upon recommendation by the chairperson. Founding members of the DBDC in 1995 included Simon Li as chairperson, Rev. Dominic Chan and Rev. Thomas Law (table 2).

Table 2 DBDC Membership (created by the author based on reference 5, 1997- 2010; information sourced by DBDC office)

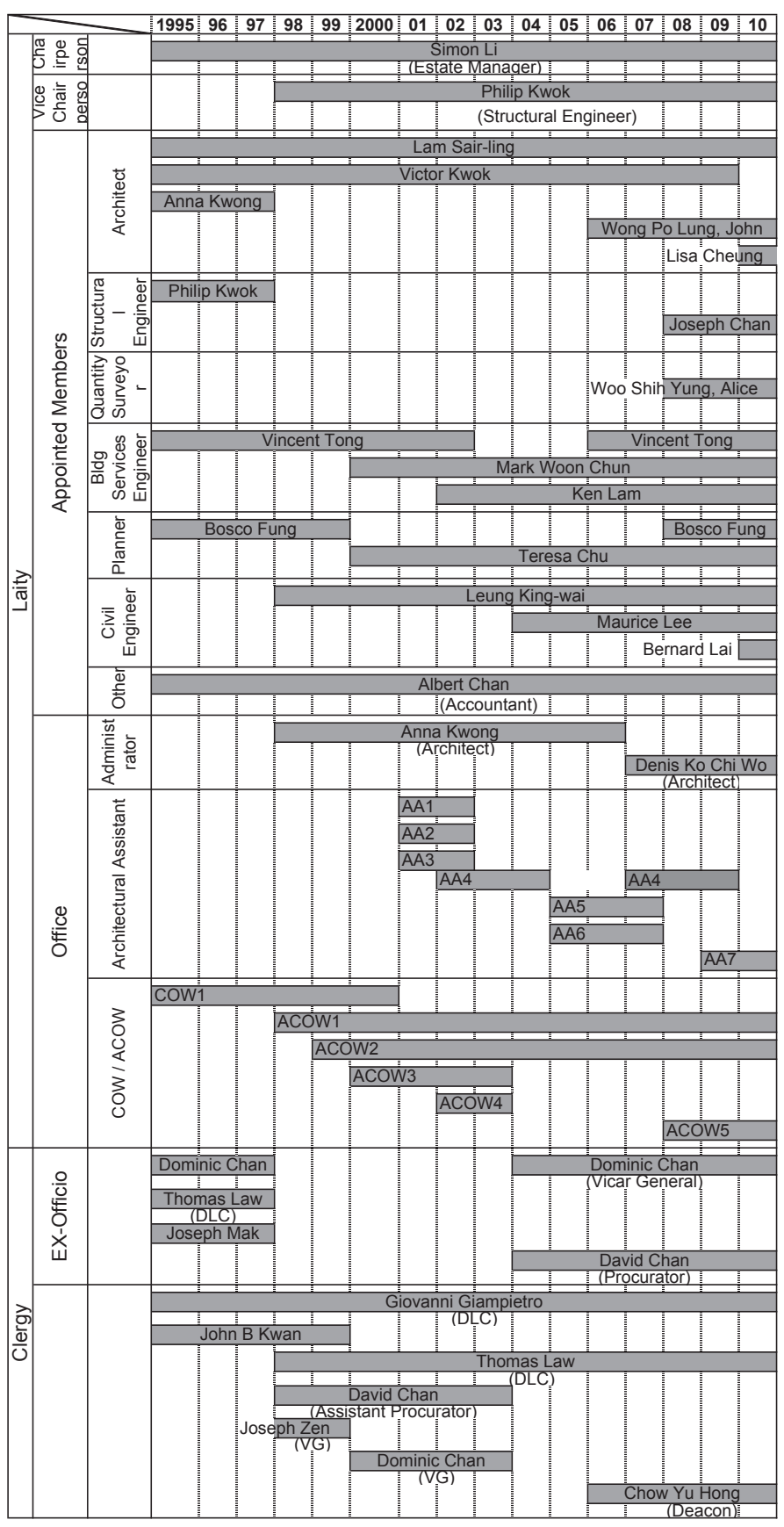


As fig. 2 illustrates, since established, the number of laity DBDC members have kept increasing; whereas, the clergy membership has slightly decreased. Most of the clergy members are also the members of the DLC(table 2).

Table 2 shows that, among the 19 laity members, 26\% are architects, $15 \%$ are structural engineers including the vice chairperson, $15 \%$ for building services engineers, $15 \%$ for planners including the chairperson, $15 \%$ for civil engineers and $5 \%$ is quantity surveyor and another $5 \%$ for financial management,

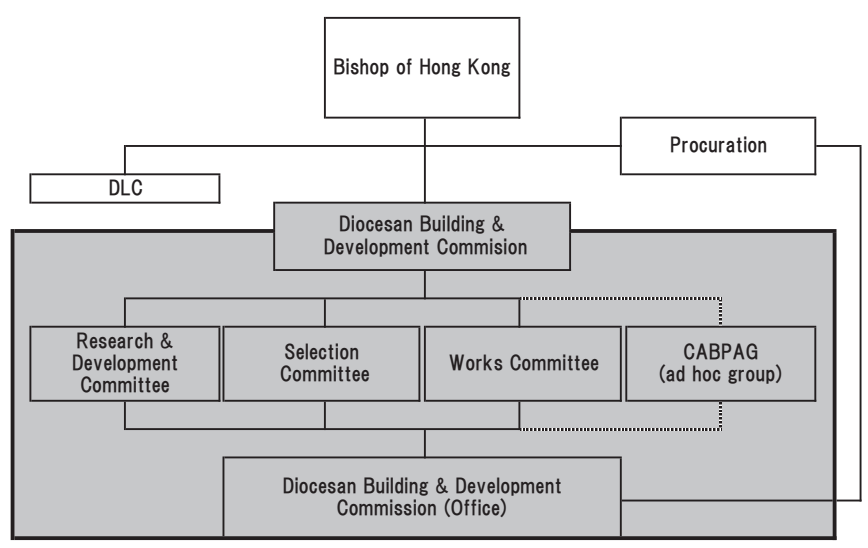

Fig.3 Organizational Structure of DBDC

(Source: "Organization" in reference 7)

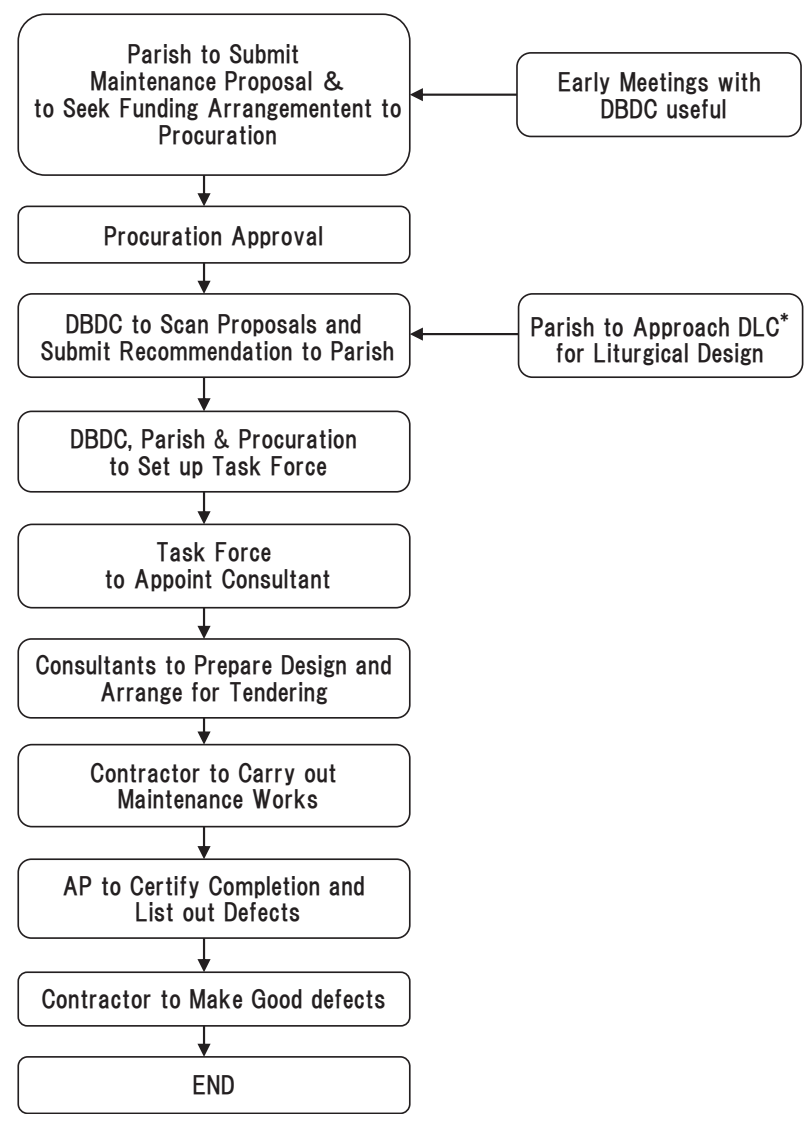

Fig.4 Flow Chart of Maintenance Works (Source: DBDC office) which is also an essential profession in the building industry.

As of 2010, among the 19 laity members, 9 members (47\%) serve more than 10 years.

These facts along with interviews with DBDC members demonstrate that the laity regards DBDC membership not as an ad hoc volunteer activity, but as a long-term professional commitment. The laity involvement is also more systematically organized and better balanced in terms of different professions than that of the previous phase.

\subsection{DBDC office}

Another significant difference from previous committees is that the DBDC has a permanent administration office(fig. 3). As table 2 shows, it employs an "Administrator", who is a full-time architect and "Authorized Person" registered by Hong Kong Government. The Administrator serves as a project manager.

As table 2 shows, the office also constantly employs an "Architectural Assistant(AA)" since 2001 and COW or Assistant COW(ACOW) since it was established. ${ }^{40)} \mathrm{AA}$ is a person with bachelor degree in architecture but not a government registered architect and an Authorized Person.

This is a significant change in the Diocesan history by establishing a permanent office with permanent professional and technical staff.

\subsection{Sub-Committees}

Fig. 3 shows that the DBDC has three permanent sub-committees plus one ad hoc group, in which each DBDC member joins one or two permanent sub-committees. As of 2009, eight members serve for the Selection Committee (SC), nine for the Works Committee (WC), and fifteen for the Research and Development Committee (RDC). ${ }^{41)}$ This section examines laity members' involvement in each sub-committee. ${ }^{42}$

\subsubsection{Selection Committee (SC)}

Laity members of the SC serve to: 1) establish approved lists of consultants and contractors for work for diocesan properties such as maintenance work, roofing and waterproofing work, electrical work, and slope repair work; 2) evaluate and consider tender submissions for projects that include periodical inspection testing, commissioning, electrical rewiring and re-enforcement along with various construction and renovation work for Diocesan properties. The SC's tendering system is similar to that of the Hong Kong Government. ${ }^{43)}$ For example in the construction project for the Our Lady of Mount Carmel Church in Wanchai, the SC prepared a list of appropriate consultants and contractors for tendering by taking into consideration the requirements of the particular project. ${ }^{44)}$

\subsubsection{Works Committee (WC)}

The WC co-ordinates with the parishes and organizations in the Diocese for the following: Design and construction of work; monitor the standard, check the progress and cost of the work; monitor and assess the performance of the building professionals and contractors employed; give advice and formulate guidelines 
on the technical and administrative aspects of building projects; and attend to emergencies related to church properties. ${ }^{45}$ Fig. 4 , the procedure of maintenance work standardized by WC, indicates that participation of each stakeholder, the procurator, DLC, DBDC, parish and parishioners, is firmly established. A project to construct a new church building also works the same as maintenance project. For example, for the construction of the Our Lady of Mount Carmel Church, a "Task Force" was formed in which a few members from the WC joined as DBDC representatives together with the procurator, DLC, parish priest, parish representatives, and the consultant architect. Generally WC members' responsibilities in a Task Force is to coordinate between the Task Force and DBDC as well as to provide professional and technical advices by attending interviews with tenderers, providing tender analysis reports, joining selection of the architect and contractor, reviewing and commenting on initial budget, development of design details and monitoring for cost control. WC representatives attend Task Force meetings and assist the parish until the handover of the building to the parish. ${ }^{46)}$ WC representatives are helpful especially when a parish does not have parishioners who are building industry professionals.

\subsubsection{Research and Development Committee (RDC)}

The RDC is responsible for research and study on Diocese's hardware needs in relation to building development in terms of pastoral and social care. ${ }^{47)}$ The RDC analyzes Catholic census and population demography in the territory, and examines which district will need a new church. It also determines the type of services; such as, special schools or classes, and services to elders that are needed in each parish. Based on the analysis, it makes suggestions to the bishop for building development. To achieve these tasks, the RDC established the system utilizing GIS. ${ }^{48}$ Based on the RDC's analysis and advice, the Diocese decided to suppress and amalgamate several parishes as well as build a new church in a New Town which was expected to have a large intake of population. ${ }^{\left.{ }^{*}\right)}$ One of the most recent church development plans in Tung Chung was implemented based on RDC's research and advice.

RDC also examines heritage designation/registration of diocesan properties when the Diocese receives such proposals from the Hong Kong Government. ${ }^{49)}$

\subsubsection{Catholic Building Professional Advisory Group (CABPAG)}

CABPAG is an ad-hoc group that provides professional advice to the Church (mostly parishes) on building, engineering and development. It also works on related matters including building management, maintenance and improvement, compliance with government regulations and requirements, contractual and liability issues, and community concerns. ${ }^{50)}$ Sub-groups are established to suit the specific needs and tasks on a flexible basis.

Though members of three permanent sub-committees need to be DBDC members, members of CABPAG do not need to be DBDC members. Instead, members are called for through self-nomination. Invited people are "all building and related professionals with a membership in relevant professional institutions or the equivalent. The list includes architects, engineers (including, but not limited to building, civil, electrical, electronics, mechanical, structural, geotechnical and building services), planners and surveyors, as well as building related experts and specialists (in lighting, acoustics, heritage and conservation, environment, design, landscaping and other relevant fields)." ${ }^{51)}$ The selection and appointment of applicants is carried out by the DBDC. This difference in membership mobilization is because the CABPAG is meant to be a pool of future DBDC members who currently do not have enough time to serve as a full DBDC member. ${ }^{52)}$

One of CABPAG's contributions is that CABPAG dispatches several members to the "Maintenance Committee" established in some parishes. The Maintenance Committee is responsible for coordinating the church property maintenance and services. For example, four members were dispatched to the Maintenance Committee of the Our Lady of Mount Carmel Parish in order to assist the parish members by advising and liaising with the DBDC through the regular participation in the Maintenance Committee's meetings. This system is effective because some major maintenance issues in a parish need to involve DBDC. ${ }^{53)}$

The laity members in DBDC play a role of adviser and monitor for the church building projects based on their professional expertise. The involvement is highly organized in the Diocesan structure and also within the commission. It is a notable difference from the participation pattern of the laity professional in the previous phase that laity professionals in DBDC are not directly engaged in design work. The design work is the task assigned to the consultant architect employed in each project. The allocation of responsibilities is clearer than in the previous phase as this system follows the standard practice employed in the building sector. It is implied that the laity members are the main and direct source, which enabled standardization of building project management in the DBDC.

\section{Conclusion}

This study set out to focus on laity professionals to identify different phases of laity involvement systematization in church building project management in the Catholic Diocese of Hong Kong since the 1960s and to reveal the situation of systematization in each phase as well as professionals involved.

Findings of this study indicate followings:

1. Three phases of laity professional involvement are identified. In the first phase from the 1960 s to the mid 1970s, there was little involvement. However, this phase laid the foundation for the actual involvement in the next phase. One of the factors 
that hindered the involvement was the traditional management practiced since the 19th century in which the clergy, particularly by the procurator and parish priests, exclusively took charge of building projects. The root of this practice comes from the particular history of the Catholic Mission in Hong Kong, which started as a Rome's financial office. However, Vatican II in the early 1960s, which included reforms of liturgical spaces, necessitated the laity involvement. The second phase is from the late 1970 s to the early 1990s. The involvement-enhancing factor observed in this phase was the DLC's initiative of creating the LAAC in the late 1970s. The continuous efforts by the DLC was accelerated by Bishop Wu's diocesan reforms in the 1980s and 1990s because those two initiatives were in line in terms of the Church's philosophy. Those efforts finally resulted in the establishment of the DBDC in 1995 which marked the third phase.that brought significant changes in the extent and contents of laity involvement.

2. In regards to the situation of systematization of laity involvement, that of the 1970s to 1980s in the second phase, as seen in the LAAC and the DCBPP, was limited in terms of the involved numbers and policy and decision-making influence. Systematization of involvement began by establishing a specialized committee. The following significant changes are found in the DBDC in the third phase. First, laity members are composed of a larger and an increasing proportion of members, and established a long-term commitment to DBDC membership. Second, laity involvement is highly organized in the Diocesan structure as well as within the commission.

3. As to laity professionals involved in the second phase, some were architects and COWs. In the third phase, nearly all laity members of the DBDC are building industry professionals. They devote their expertise by acting as advisors and inspectors for the client team throughout the project process. The lay professional expertise in sub-committees was the main reason for the establishment of standardized building project management as well as equal participation of each stakeholder in building projects. Laity involvement in the DBDC became substantial in policy and decision-making.

\section{References}

*1) Schloeder, S: J. Architecture in Communion: Implementing The Second Vatican Council Through Liturgy and Architecture, Ignatius, 1998

*2) Ha, Louis: The Foundation of the Catholic Mission in Hong Kong 18411894, The University of Hong Kong, 1998, Ph.D thesis

*3) Li Ng, Suk-Kay: Mission Strategy of the Roman Catholic Church of Hong Kong 1949 to 1974, The University of Hong Kong, 1978, Master of Philosophy's thesis.

*4) Ticozzi, S: Historical Document of the Hong Kong Catholic Church, Hong Kong Catholic Diocesan Archives, 1997, p.232

*5) Catholic Truth Society: Catholic Church Directory, Catholic Truth Society, 1953-2010

*6) Hong Kong Catholic Diocesan Archives: March into the Bright Decade: Pastoral Letters of Cardinal John B. Wu, Hong Kong Catholic Diocesan Archives, 2005, p.562
*7) Diocesan Building and Development Commission: http://www.dbdc. catholic.org.hk/. accessed on 2010-07-01

\section{Notes}

1) "Building project" refers to, in this paper, construction, renovation, restoration, conservation and maintenance works of a part of or a whole worship places or their sites. "Management" refers to developing project plans, financing, scheduling, monitoring/quality-controlling of building projects and managing communication among project stakeholders/project team.

2) The definition of "worship places" in this study is places where Catholic worship are/were held. Worship places include church, chapel, and mass center. Church is a space solely dedicated to religious activities. Some churches are embedded in school building or a multi-functional building. Chapel refers to any small place of worship which is usually privately owned by convents etc. and used by small group gathering. Mass centers are used for mass and other services and activities. In Hong Kong the name of worship place type changes from time to time. In the 1960 s to the 1970 s, worship places categorized as "Missionary Station" existed. Missionary station was a temporal space used for mission works, therefore, often rented spaces. In the 1980s, Missionary Stations were reformed into mass centers.

3) The Vatican(Roman Curia) does not apply any standardized and uniform church building management system to all the dioceses and parishes around the world. The previous study about Japanese Catholic churches indicates that there is no such a systematized laity involvement in Japan(Kikata, J. Fukushima, A. et al.: 九州離島のキリス卜教系集落の維持 管理活動に関する研究 - 過疎集落における文化的景観の継承手法の確立に 向けて -(A study on spatial management activities in Christian villages in Kyushu Region - Towards a sustainable management system for cultural landscapes in depopulated villages -), Journal of Housing Research Foundation, No.36, 2010, pp.71-82) This study does not represent church building management by laity in all other areas in Japan but shows one of many diverse laity involvement patterns. Other previous study on this subject cannot be found.

4) In this paper, Church(capitalized) refers to the apostolic institution or a group of Catholics including both of clergy and laity, and church(lower case) to the building being one part of apostolic Church; reference 1, p.267 5) reference 2 , pp.67-68.

6) reference 3.

7) Detailed contents of contributions by laity professionals in actual building projects are to be examined in the separate papers.

8) reference 2 , p.vii.

9) reference 2, p.331.

10) "Plan for the Reorganization of the Diocese in Historical Documents of the Hong Kong Catholic Diocese" in reference 4, p.210.

11) The number of Catholics during 1930-1946 excluding 1939 and worship places during 1930-1958 has not been researched and identified yet.

12) reference 3, p. 142 .

13) reference 3, p. 275 .

14) reference 3, p.295.

15) Li, Simon. Interview by author. Hong Kong, 24 March 2010; Law, Thomas. Interview by author. Hong Kong, 26 March 2010.

16) reference 3, p.294.

17) Ibid.

18) reference 3, p.211.

19) reference $1, \mathrm{p} .16$.

20) Report of Hong Kong Diocesan Liturgical Commission.(in Chinese) Jian: for the life of the world: Newsletter of the Hong Kong Diocesan Liturgical Commission. 1988, vol. 4, p.11.

21) Liturgical Art and Architecture Research Group. Jian: for the Life of The World: Newsletter of the Hong Kong Diocesan Liturgical Commission. 1977, vol.1.

22) reference 5, 1978; Ahearn, John. Email correspondence by author. 24 Feb, 2011.

23) Ahearn, John. Email correspondence by author. 24 Feb, 2011. 
24) reference 5, 1983

25) reference 3, pp.291-292.

26) reference 3, p.322.

27) Law, Thomas. Interview by author. Hong Kong, 26 March 2010.

28) reference 3, pp.329-331.

29) reference 5, 1968-1984

30) Khong, Edward. An Evaluation of "Establishment of a Client Body for All Construction, Alteration \& Maintenance Works of the Hong Kong Diocese" as proposed by The Liturgical Art \& Architecture Group of H.K. Diocesan Liturgical Commission on 30th May, 1988.(an internal report), 1992 Sep 21, p.6, DLC Office.

31) Khong, Edward. Interview by author. Hong Kong, 27 Sep, 2010.

32) See note 15 above.

33) Ahearn, John F. A House for the Church. Jian: Newsletter of the Hong Kong Diocesan Liturgical Commission. 1987, vol.2, pp.1-11.

34) See note 30 above.

35) reference 6, p.260.

36) Appendix The Consultation Report on the Direction of the Catholic Diocese of Hong Kong for the Next Ten Year. in reference 6, p.281.

37) The Plan. in reference 4, pp.201-218.

38) DLC. Diocesan Planning and Land/Building Development Commission. DLC, 1992 Nov 10, DLC Folder "Client Body"(internal report), p.8, DLC Office.

39) See note 15 above.

40) Upon the establishment of DBDC in 1995, a COW who was working at the Diocesan Procuration, was transferred to DBDC office(source from note 31 above).

41) Lam, Sair-ling. Interview by author. Hong Kong, 19 September 2009.

42) Further detailed contents of involvement will be discussed in the separate paper.

43) "Selection committee". in reference 7. (accessed on 2010-07-01)

44) Lam, Sair-ling. Email correspondence by author. 28 February 2011.

45) "Works Committee". in reference 7. (accessed on 2010-07-01)

46) See note 44 above.

47) "About us". in reference 7. (accessed on 2010-07-01)

48) DBDC Meeting Minutes of June 1999. DBDC office.

49) See note 41 above.

50) "Recruitment". in reference 7. (accessed on 2010-07-01)

51) Ibid.

52) "Related Links Internal" in reference 7. (accessed on 2010-07-01)

53) Li, George. Interview by author. Hong Kong, 26 September 2010.

\section{和文要約}

カトリック香港教区では、教会堂をはじめとする教区所有建造物 の建設事業に、一般信徒が深く関与していることが他の教区には見 られない特徵である。

一般信徒参画は、1960 年代初頭の第二バチカン公会議を契機とし て模索され始め、1995 年には「建築及び発展委員会 (DBDC)」が設 立されて今日に至っている。本稿では、一般信徒参画が確立されて いったプロセスを追いながら、その背景や理念、具体的なありかた を明らかにした。香港カトリック・ミッションは 19 世紀にバチカ ンの財務オフィスとして出発したことに起因する、教区財務部を中 心とする聖職者のみによる建設事業管理手法が、一般信徒の参画を 阻んできた要因であることが明らかになった。また、一般信徒参画 の契機となった要因は、第二バチカン公会議であり、更にその後の 典礼委員会による一般信徒専門家の参画促進の取り組みにあること が分かった。また、この取り組みは、当時の司教の教区組織改革と 時を同じくし、また理念も同じくしていたために、加速され、最終 的に 1995 年の「建設及び発展委員会 (DBDC)」の設立に至ったこと が明らかになった。1995 年以前に存在した建設事業関係の教区委員 会では、一般信徒の参画は、人数と政策・意思決定の面において極 めて限定的なものであったが、対照的に、DBDC においては、一般信 徒委員は、聖職者に比して圧倒的に多く、かつ増加しており、かつ、 ほぼ全員が建設産業の専門家で構成されていることが明らかになっ た。また、DBDC における一般信徒専門家の本質的かつ長期的な貢献 によって、建設事業管理の手法が標準化・透明化されたと考えるこ とができる。一般信徒専門家の教区建設事業への参加は、DBDC の設 立により、本質的かつ不可欠のものとして香港教区において確立さ れた。

(2010年 7 月 28 日原稿受理， 2011年 5 月23日採用決定） 